\title{
STRATEGI PENGEMBANGAN DESTINASI WISATA DESA SELONG BELANAK, KABUPATEN LOMBOK TENGAH NUSA TENGGARA BARAT
}

\author{
Awal Kasian \\ Mahasiswa Pascasarjana UIN Mataram \\ awaljabon@gmail.com
}

abstrak. Penelitian ini menganalisis strategi pengembangan Desa Selong Belanak, Kabupaten Lombk Tengah, Nusa Tenggara Barat, sebagai tujuan wisata. Desa ini memiliki potensi sumber daya alam dan budaya yang besar tetapi belum sepenuhnya berkembang sebagai tempat wisata. Studi ini dimulai dengan mengidentifikasi potensi wisata desa dan diikuti dengan menyusun strategi untuk mengembangkan desa sebagai tujuan wisata yang menarik. Penelitian ini menggunakan analisis data deskriptif kualitatif dan analisis SWOT. Hasil penelitian menunjukkan bahwa potensi wisata desa Selong Belanak meliputi sumber daya wisata alam, potensi ekonomi sosial dan budaya, aksesibilitas dan fasilitas pendukung, yang belum digunakan dan dikelola dengan baik. Selain itu, beberapa fasilitas dan infrastruktur publik tidak memadai. Studi ini menunjukkan bahwa ada perlunya keterlibatan pemerintah dalam membangun lembaga pengelolaan pariwisata, meningkatkan kualitas sumber daya manusia, membangun infrastruktur fasilitas wisata yang masih kurang, serta membentuk kerja sama yang erat antara pemangku kepentingan pariwisata termasuk masyarakat .

\section{Kata kunci: Potensi Wisata, Strategi Pengembangan, Komunitas, Desa Selong Belanak}

\section{PENDAHULUAN}

Indonesia merupakan daerah yang sangat luas, terdiri dari lebih dari 17 ribu pulau, dan tiap-tiap daerahnya memiliki potensi alam yang indah dan budaya yang unik. Keindahan alam dan budaya lokal itu merupakan potensi besar untuk dikembangkan sebagai daya tarik wisata dan dikelola sebagai salah satu sumber daya ekonomi masyarakat setempat. Dalam beberapa hal, pariwisata juga memberikan kontribusi dalam pengentasan kemiskinan (Putra dan Pitana 2010). Sejauh ini, belum semua potensi wisata daerah-daerah di Nusantara dikembangkan dengan baik. Persoalannya adalah belum semua daerah memiliki akses yang memadai, sementara itu semangat rintisan kurang kuat. Salah satu cara untuk mengatasi hal ini adalah mendesaknya disusun langkah strategis untuk pemanfaatan sumber daya alam untuk pariwisata.

Pemerintah perlu turut serta mendorong terbentuknya badan pengelola destinasi wisata di daerah-daerah. Badan ini akan bertugas untuk mengoptimalkan sumber daya untuk mendorong terwujudnya harapan mendatangkan wisatawan, penyediaan jasa, dan menciptakan lingkungan yang mampu mendukung terwujudnya kegiatan dalam bentuk kebijakan, peraturan, dan insentif (Hermantoro, 2011:22).

Desa Selong Belanak, terletak $74 \mathrm{~km}$ dari Ibu Kota Provinsi Nusa Tenggara Barat . Provinsi ini merupakan satu daerah yang memiliki potensi sumber daya alam (SDA) yang menakjubkan. Sumber daya alam itu antara lain pegunungan, yang sering dijadikan objek perkemahan atau pun kegiatan-kegiatan wisata seperti Viu Pantai. Di desa ini juga terdapat lahan perkebunan yang luas, karena sebagian dari masyarakat Desa Selong Belanak merupakan petani. Wisatawan dapat menyaksikan sekaligus ikut berkebun dengan masyarakat di lahan perkebunan yang terletak di bukit-bukit desa.

Keindahan pantai Selong Belanak sebagai tempat para wisatawan lokal berekreasi menikmati keindahan laut. Sementara untuk potensi sumber daya buatan (SDB) seperti potensi pembangunan Villa dan hotel-hotel 
yang berada di atas bukit Desa Selong Belanak;

Desa Selong Belanak letaknya sangat strategis karena berdekatan dengan tempattempat wisata lainnya. Letak seperti ini akan menarik jika dikemas menjadi produk perjalanan wisata. Objek wisata yang berdekatan dengan Desa Selong Belanak di antaranya adalah Pantai Kute yang terkenal dengan wilayah KEK (Kawasan Ekonomi Khusus) dan tempat terselanggaranya motogp. Objek ini selalu ramai dikunjungi wisatawan karena pantainya yang indah. Pengembangan pariwisata yang ideal akan selalu menunjukkan kepedulian terhadap pelestarian lingkungan, melibatkan pemerintah dan masyarakat lokal. Pengembangan pariwisata yang melibatkan masyarakat sangat penting untuk membuka lapangan kerja, memberikan pemahaman tentang pariwisata, dan meningkatkan kondisi perkonomian masyarakatnya. Pariwisata memiliki prospek yang sangat besar jika dikembangkan dengan baik, melalui pembenahan sarana dan prasarana serta partisipasi masyarakat. Untuk dapat mengembangkan dan memajukan kegiatan pariwisata tersebut, diperlukan sebuah pengelolaan yang baik dengan didukung oleh sumber daya manusia yang ahli, berpengalaman, dan berkomitmen dalam bidang pariwisata.

Terbatasnya fasilitas pendukung menjadi hambatan pelaksanaan kegiatan pariwisata di Desa Selong Belanak . Wisatawan masih enggan untuk mengunjungi atau pun berlama-lama berada di desa ini karena segala sesuatu yang mungkin mereka butuhkan belum tersedia. Hal ini juga yang dapat memicu rendahnya angka wisatawan yang berkunjung ulang sebagai repeater tourist.

Pada dasarnya pengembangan pariwisata di Desa Selong Belanak sangat penting untuk dilakukan. Pengembangan pariwisata di Desa Selong Belanak akan memberikan perubahan dan keberlangsungan baik jangka pendek maupun jangka panjang bagi masyarakat lokal dan pemerintah Desa Selong Belanak.

Berdasarkan latar belakang masalah tersebut, maka masalah penelitian ini dirumuskan sebagai berikut: apa potensi pariwisata Desa Selong Belanak Kecamatan Praya Barat, Kabupaten Lombok Tengah. bagaimana strategi pengembangan potensi tersebut sehingga Desa Selong Belanak dapat menjadi destinasi wisata yang mampu menarik banyak wisatawan.

\section{TEORI DAN METODE}

Teori yang digunakan untuk menjawab persoalan di atas adalah pengembangan pariwisata dan teori siklus hidup destinasi wisata. Teori pengembangan pariwisata yang relevan adalah pengembangan objek dan daya tarik wisata perdesaan yaitu dengan menggunakan community approach atau community based development. Hal ini disebabkan karena masyarakat lokal yang akan membangun, memiliki dan mengelola langsung fasilitas wisata serta pelayanannya, sehingga dengan demikian masyarakat dapat menerima secara langsung keuntungan ekonomi serta mencegah langsung terjadinnya urbanisasi.

Dalam pengembangan, baik pengembangan destinasi, kawasan pariwisata, dan objek serta daya tarik wisata pada umumnya mengikuiti alur hidup pariwisata (Marpaung, 2002:49). Dalam proses pengembangan pariwisata, perencanaan matang dan strategis sangat diperlukan. Menurut Mill (2000: 193), bila tidak adanya perencanaan pada sebuah tempat tujuan wisata dapat berakibat negatif pada daerah tersebut.

Teori siklus hidup destinasi wisata (tourism destination lifecycle) yang diperkenalkan oleh Richard Butler tahun 1980 adalah konsep hipotetik untuk memahami evolusi atau perkembangan dari sebuah destinasi pariwisata. Pembabakan evolusi ditakar dengan dua hal yaitu jumlah wisatawan yang berkunjung ke suatu objek dan rentang waktu perjalanan evolusi destinasi.

Untuk mengetahui perumusan pengembangan pariwisata terhadap objek dan 
daya tarik wisata maka sangat diperlukan suatu tahapan dimana pengembangan pariwisata tersebut mampu berdiri sekarang ini. Tahapan pengembangan pariwisata membawa implikasi serta dampak yang berbeda. Menurut Richardson dan Fluker, (2004: 51) yang dimaksud dengan model siklus hidup destinasi (destination lifecycle model) adalah sebagai berikut:

A model that characterises each stage in the lifecycle of a destination (and destination areas and resort area) including introduction, growth, maturity, and decline and/or rejuvenation.

Seperti ditegaskan dalam kutipan di atas, siklus hidup daerah wisata ditandai dalam beberapa tahap yaitu tahap pengenalan (introduction), pengembangan (growth), pematangan (maturity), dan dari sini ada dua kemungkinan yaitu penurunan (decline) karena kejenuhan atau peremajaan (rejuvenation). Kelengahan dalam mengelola suatu destinasi akan menyebabkan penurunan, ditandai dengan ditinggalkannya destinasi tersebut oleh wisatawan, namun sebaliknya kesungguhan dan inovasi-inovasi pengelolaan akan memungkinkan destinasi tersebut untuk tetap memikat wisatawan.

Selain dengan pengamatan, metode yang diterapkan dalam penelitian ini adalah melakukan wawancara dengan informan, focus group discussion (FGD), dan studi dokumentasi. Data yang diperoleh dianalisis dengan teknik analisis deskriptif kualitatif dan analisis SWOT.

\section{Potensi Pariwisata di Desa Selong Belanak}

Seperti sudah disebutkan sepintas di awal tulisan ini, potensi wisata Desa Selong Belanak demikian banyak dan bisa dikategorikan menjadi tiga yaitu potensi wisata alam, budaya, dan potensi buatan. Masing-masing dari potensi itu didata per kelompok berikut ini

\section{Potensi Wisata Alam}

a) Aktivitas Alam. Keindahan alam pegunungan menjadi modal bagi pengembangan pariwisata Desa Selong Belanak . Para wisatawan berkesempatan menambah pengalaman mereka dengan melakukan hiking dan rekreasi alam lainnya di pegunungan.

b) Aktivitas Pertanian. Pertanian di Desa Selong Belanak bukan merupakan mata pencaharian utama bagi masyarakat Desa Selong Belanak . Aktivitas pertanian yang dilakukan adalah jenis pertanian lahan kering. Kegiatan pertanian merupakan daya tarik wisata selain potensi ekologis. Kegiatan pertanian di Desa Selong Belanak masih menggunakan cara-cara tradisional, dengan menggunakan cangkul untuk mengerjakan kebun, selain itu karena lahannya yang berbukit-bukit. Kegiatan yang masih tradisional inilah menjadi daya tarik bagi wisatawan, karena dianggap unik sehingga memunculkan keingintahuan mereka terhadap aktivitas masyarkat tersebut. Lahan dan bibit telah disiapkan oleh masyarakat Desa Selong Belanak .

c) Aktivitas Nelayan. Aktivitas nelayan merupakan mata pencaharian utama bagi masyarakat Desa Selong Belanak. Potensi laut dan pantai Selong Belanak merupakan sumber daya andalan. Pantai Selong Belanak ini mempunyai pasir putih dan ombak ombak biru yang indah. Wisatawan bisa melakukan kegiatan surfing di pantai ini karena ombaknya yang tinggi dan lautnya yang tenang, dapat menikmati keindahan laut, serta bisa ikut dengan para nelayan yang sedang menangkap ikan. Wisatawan juga dapat menikmati suasana sunset di pesisir Pantai Selong Belanak. Mayoritas pengunjung pantai ini adalah wisatawan lokal. Daya tarik pantai ini adalah pantai yang berpasir putih dan tempat menyaksikan sunset bersama nelayan Desa Selong Belanak. Adapun suasana aktivitas di Pantai Selong Belanak.

\section{Potensi Sumber Daya Buatan}

Selong Selo Residence. Villa ini terletak di atas bukit, dengan pemandangan laut yang indah. Laut biru dan nyiur melambai membuat 
bentang alam tropis yang mewujudkan saujana alam dan arsitektur yang mengagumkan . Bentuk bangunan ini merupakan campuran arsitektur modern dengan budaya lokal masyarakatnya.. Biasanya villa ini ramai di kunjungi oleh wisatawan setiap hari sabtu dan minggu Jarak dari Kota Kabupaten 32 km, bisa ditempuh sekitar 35 menit dengan kenderaan roda dua dan roda empat. Selama perjalanan menuju tempat ini anda bisa menikmati pemandangan alam yang sangat indah.

\section{Potensi Budaya}

Kesenian tradisional. Potensi seni budaya yang dapat dijadikan atraksi atau daya tarik wisata Desa Selong Belanak adalah budaya Gendang Beleq. Atraksi ini dapat disaksikan oleh wisatawan pada acara nyongkolan adat sasak

Gendang Beleq ini biasa dipentaskan pada upacara adat pernikahan, dipersembahkan khususnya untuk mengiringi pengantin pria dan wanita pada saat kunjungan ke rumah pengantin wanita.

Dalam rangka melesatarikan kebudayaan yang ada di Desa Selong Belanak pemerintah Kabupaten Lombok Tengah melakukan berbagai upaya. Salah satunya yaitu menyelenggarakan Festival Gendang Beleq setiap tahunnya. Festival ini merupakan acara kebudayaan turun temurun yang dilaksanakan setiap tahun. Kegiatan ini bertujuan untuk melestarikan dan memperkenalkan budaya dan adat istiadat setempat kepada para wisatawan yang berkunjung ke Desa Selong Belanak Bau Nyale. Bau Nyale merupakan acara penangkapan cacing laut yang disebut nyale . konon ceritanya cacing laut ini berasal dari penjelmaan seorang putri yang menghanyutkan diri ke laut karena tidak biasa memilih salah satu dari sekian banyak pangeran yang melamarnya. Bau nyale biasa dilakukan pada bulan februari di pagi hari sebelum subuh. Para wisatawan biasa ikut langsung menangkap nyale bersama dengan penduduk desa Selong Belanak. Penangkapan nyale ini biasa dilakukan dengan tangan secara langsung atau dengan alat yang disebut sorok atau jaring.

\section{Fasilitas Pendukung Pariwisata}

Perkembangan destinasi pariwisata sangat dipengaruhi oleh beberapa fasilitas di antaranya fasilitas pendukung seperti transportasi, pendidikan, dan kesehatan. Adapun fasilitas pendukung adalah adanya sebuah Sekolah Menengah Kejuruan Pariwisata (SMK), yang ada di Desa selong belanak.

Sarana wisata merupakan kelengkapan daerah tujuan wisata yang diperlukan untuk menikmati perjalanan wisata ke Desa Selong Belanak . Berdasarkan potensi alam dan budaya yang dimiliki Desa Selong Belanak, kunjungan wisatawan dengan tujuan menikmati potensi yang masih alami semakin meningkat. Usaha pariwisata sudah mulai berkembang. Begitu banyak penginapan-penginapan yang dibangun. Seperti, villa kotak, villa indah, tiki lodge, villa kelapa dan masih banyak lagi.

Masyarakat dipercayakan untuk mengelola homestay dan membentuk suatu badan pengelola yang bekerjasama dengan pemerintah Desa Selong Belanak untuk mengatur usaha homestay.

\section{Aksesibilitas}

Infrastruktur, merupakan salah satu aspek yang sangat penting seperti jalan yang menuju ke Desa Selong Belanak yang dapat ditempuh hanya melalui dua arah, yakni jalur timur dan utara. Jalan yang menuju pusat pemerintahan desa dengan dusun-dusun yang ada di wilayah Desa Selong Belanak sebagian besar jalan beraspal.

\section{Srategi Pengembangan Bongo sebagai Destinasi Wisata}

Agar dapat merumuskan strategi pengembangan destinasi wisata dan peningkatan kunjungan wisatawan yang tepat terhadap destinasi pariwisata di Desa Selong Belanak , perlu diketahui fase-fase perkembangan pariwisata sesuai dengan teori yang digunakan dalam penelitian ini yaitu teori siklus hidup destinasi yang diperkenalkan Butler (1980). Terdapat tujuh fase perkembangan pariwisata yaitu penemuan (exploration), keterlibatan (involvement), 
pembangunan (development), konsolidasi (consolidation), stagnasi (stagnation), penemuan (decline), dan peremajaan (rejuvenation). Setelah dilakukan pengamatan maka destinasi pariwisata Desa Selong Belanak tergolong ke dalam fase involvement (keterlibatan) yaitu fase kedua yang ditandai dengan meningkatnya jumlah kunjungan wisatawan. Dari fase keterlibatan hingga sekarang mulai berkembang ketahap selanjutnya yaitu fase pembangunan, yang sesuai dengan siklus hidup destinasi dan strategi pengembangan pariwisata.

SWOT merupakan pendekatan yang digunakan untuk merumuskan srategi pengembangan dan peningkatan kunjungan wisatawan ke Desa Selong Belanak . Sesuai dengan kondisi dan keadaan Desa Selong Belanak , hal ini berdasarkan pada memaksimalkan kekuatan (Strengths) dan peluang (Opportunities), namun secara bersamaan dapat meminimalkan kelemahan (Weaknesses) dan ancaman (Threats) (Rangkuti, 2005:19). Berikut ini diuraikan pendekatan SWOT untuk mengkaji kondisi internal dan eksternal Desa Selong Belanak dalam pengembangan pariwisata.

\subsection{Analisis Internal}

\section{a) Kekuatan}

Kekuatan adalah segala sesuatu yang dapat dikembangkan sebagai andalan pengembangan dan peningkatan kunjungan wisatawan ke Desa Selong Belanak meliputi potensi ekologis, sumber daya buatan, potensi budaya dan sosial ekonomi, sehingga nantinya bisa bersaing dengan tujuan wisata lain. Variabel-variabel yang menjadi pedoman dalam melihat kekuatan yang dimiliki terdiri atas kondisi alam Desa Selong Belanak, kondisi suhu yang cukup baik, adat nyongkolan, tingkat aksesibilitas, keramah-tamahan penduduk, dan dukungan masyarakat lokal dan partisipasi pemerintah.

\section{b) Kelemahan}

Kelemahan merupakan suatu keadaan pada objek yang kurang mengun-tungkan dalam pengembangan pariwisata Desa Selong
Belanak melalui beberapa atraksi yang berbasis masyarakat. Kelemahan ini perlu diatasi sehingga layak dikembangkan dan tidak memberikan dampak negatif terhadap fak-tor dari luar yang mempengaruhi faktor eksternal tersebut yaitu kurangnya produk kerajinan lokal, kurangnya minat/ perhatian masyarakat terhadap pengembangan pariwisata pantai dan pertanian, kurangnya infrastruktur yang menunjang pariwisata, rendanya Sumber Daya Masyarakat lokal, tidak adanya pengelola resmi oleh masyarakat lokal, dan tidak adanya bantuan dari Pemerintah.

\subsection{Analisis Eksternal}

\section{a) Peluang}

Peluang merupakan segala sesuatu yang memberikan kesempatan untuk meningkatkan pengembangan Desa Selong Belanak . Adapun peluang yang dimaksud yaitu kemajuan teknologi dan transportasi, pariwisata dunia, segmen pasar yang kuat dan adanya sekolah SMK Pariwisata.

\section{b) Ancaman}

Ancaman merupakan dampak negatif yang akan ditimbulkan dari faktor-faktor eksternal yang harus diantisipasi agar tidak menimbulkan kerugian terhadap pengembangan pariwisata di Desa Selong Belanak . Yang termasuk ancaman tersebut di antaranya persaingan produk wisata/destinasi lain, rusaknya lingkungan; pengaruh budaya luar, ketergantungan yang berlebihan pada pariwisata, naiknya harga tanah/lahan, isu keamanan nasional.

\section{Strategi Pengembangan Pariwisata Desa Selong Belanak}

Berdasarkan analisis pada faktor internal dan eksternal dengan menggunakan matrik SWOT dapat dirumuskan beberapa strategi seperti Strategi SO (Strengths Opportunities), Strategi WO (Weaknesess Opportunities), Strategi ST (Strenghts Threats), Strategi WT (Weaknesses Threats) yang merupakan kombinasi fakta - fakta dari internal dan eksternal. Selanjutnya diuraikan setiap strategi yang akan digunakan dalam 
pengembangan pariwisata di Desa Selong Belanak adalah seperti berikut.

Strategi SO. Merupakan strategi yang menggunakan kekuatan untuk memanfaatkan peluang antara lain merancang paket atraksi wisata seperti paket atraksi Budaya Walima dan paket wisata pantai dan pertanian,

meningkatkan promosi daya tarik wisata diantaranya memperluas pangsa pasar lewat media cetak dan elektronik dan melakukan promosi melalui Biro Perjalanan Wisata.

Srategi ST merupakan strategi yang menggunakan kekuatan untuk mengatasi ancaman antara lain perencanaan pengembangan, menyusun regulasi yang mengatur dan membatasi pembangunan yang daapat merusak potensi ekologis, di antaranya membentuk lembaga pengawas konservasi lingkungan desa dan membentuk lembaga adat, meningkatkan keamanan dan kenyamanan kawasan destinasi wisata seperti menjaga keamanan di lingkungan pariwisata Desa Selong Belanak dan menciptakan kewaspadaan terhadap teroris.

Strategi WO merupakan strategi yang meminimalkan kelemahan untuk memanfaatkan peluang, antara lain meningkatkan kualitas sumber daya manusia melalui pengadaan pelatihan pariwisata kepada masyarakat lokal dan pengadaan sekolah menengah kejuruan pariwisata (SMK Pariwisata), revitalisasi budaya dan kerajinan lokal seperti menghidupkan/menggali budaya yang ada di Desa Selong Belanak, meningkatkan produksi para pengrajin lokal, kerjasama antar pelaku usaha dengan tokoh lokal, dan keterlibatan masyarakat lokal.

Strategi WT merupakan strategi yang meminimalkan kelemahan untuk menghindari ancaman. Dari WT dapat diformulasikan beberapa strategi antara lain membentuk lembaga pengelolaan pariwisata Desa Selong Belanak dan badan promosi pariwisata desa, menjaga kelestarian lingkungan dan konservasi alam Desa Selong Belanak diantaranya menjaga kebersihan lingkungan, menjaga potensi ekologis dan keindahan alamnya, kontribusi pariwisata bagi perekonomian lokal (desa).

\section{PENUTUP}

Berdasarkan hasil pembahasan dan analisis data dari penelitian yang dilakukan maka dapat disimpulkan hal-hal sebagai berikut. Dalam penelitian ini beragam potensi pariwisata yang terdapat di Desa Selong Belanak yang telah diindentifikasi menjadi daya tarik wisata di antaranya adalah potensi wisata alam yang terdiri dari aktivitas alam pegunungan, aktivitas pertanian, aktivitas nelayan; potensi sumber daya buatan berupa potensi saujana Masjid Walima Emas dan Meseum Goa/Batu; potensi budaya yaitu kesenian tradsional berupa tarian seni bela diri (Longgo Tulaibala), tarian pengantin (Saronde dan Tidi), dan budaya dzikir (Dikili); atraksi budaya tradisional masyarakat desa dalam merayakan kelahiran Nabi Muhammad SAW (Walima); pasar tradisional merupakan pasar subuh yang masih menggunakan sistem barter; fasilitas pendukung dengan adanya sarana wisata yang memadai seperti adanya sebuah sekolah menengah kejuruan pariwisata (SMK) dengan lahan parkir yang luas dan fasilitas toilet yang ada di dalamnya, empat penginapan berbentuk walima (wombohe), satu restoran dan satu art shop; aksessibilitas yang sangat mudah diakses oleh wisatawan yaitu dapat ditempuh melalui dua jalur darat dan satu jalur laut, jalur darat bisa di tempuh melalui jalur utara dan timur, untuk jalur laut bisa melalui Teluk Tomini.

Berdasarkan analisis internal dan eksternal dengan menggunakan matrik SWOT, dapat dirumuskan strategi inti untuk pengembangan destinasi wisata dan peningkatan kunjungan wisatawan ke Desa Selong Belanak sebagai berikut. Strategi SO. Strategi SO merupakan strategi yang menggunakan kekuatan untuk memanfaatkan peluang menghasilkan strategi merancang paket atraksi wisata, meningkatkan promosi daya tarik wisata. Strategi ST. Strategi ST merupakan strategi yang menggunakan kekuatan untuk mengatasi ancaman 
menghasilkan strategi perencanaan dan pengembangan, membentuk/ membuat peraturan lokal yang mengatur dan membatasi pembangunan yang dapat merusak potensi ekologis, meningkatkan keamanan dan kenyamanan kawasan destinasi wisata. Strategi WO. Strategi WO merupakan strategi yang meminimalkan kelemahan untuk memanfaatkan peluang menghasilkan strategi meningkatkan kualitas sumber daya manusia (SDM), revitalisasi budaya dan kerajinan lokal, kerjasama antar pelaku usaha dan tokoh lokal. Strategi WT. Strategi WT merupakan strategi yang meminimalkan kelemahan untuk menghindari ancaman, menghasilkan strategi membentuk lembaga pengelolaan pariwisata, menjaga kelestarian lingkungan dan konservasi alam Desa Selong Belanak, kontribusi pariwisata bagi perekonomian lokal.

\section{SARAN}

Saran yang dapat direkomendasikan kepada pihak-pihak terkait dari hasil pembahasan adalah sebagai berikut. Pemerintah perlu membentuk suatu lembaga pengelola, meningkatkan kualitas sumber daya manusia, membangun infrastruktur pariwisata yang masih kurang. Untuk membangun infrastrukturt tersebut pemerintah dapat bekerja sama dengan investor. Bagi pengelola perlu adanya kerja sama yang baik antara pemerintah sebagai fasilitator, swasta dan masyarakat lokal untuk bekerja sama sehingga kedatangan wisatawan dan segala aktivitas wisata yang berkembang di Desa Selong Belanak dapat terkontrol dengan baik di bawah pengawasan masyarakat. Bagi masyarakat, perlu menjaga kebersihan dan keamanan lingkungan dengan mempertahankan keindahan potensi alam dan budaya yang ada di Desa Selong Belanak.

\section{DAFTAR PUSTAKA}

Butler, R.W.1980. The Concept of Tourism Area Cycle Of Evolution: Implications for the Management of Resources. The Canadian Geographer Vol. 24:5-12.

Hermanoro, Henky. 2011. Creative-Based Tourism: Dari Wisata Rekreatif Menuju Wisata Kreatif. Depok: Aditri.
Juhanda. 2004. "Formulasi Strategi Pengembangan Pariwisata di Kabupaten Situbondo" (Tesis). Denpasar: Pascasarjana Universitas Udayana.

Marpaung, Happy. 2002. Pengantar Pariwisata. Bandung: Alfabeta

Mill, Robert Christie. 2000. Tourism The International Business (Alih Bahasa Sastro Tribudi). Jakarta: PT Raja Grafindo Persada.

Pitana, I Gede dan Putu G. Gayatri. 2005. Sosiologi Pariwisata: Kajian Sosiologis Terhadap Struktur, Sistem, dan Dampak - dampak Pariwisata.Yogyakarta: ANDI.

Pitana, I Gede dan Surya Diarta, I Ketut. 2009. Pengantar Ilmu Pariwisata. Yogyakarta: ANDI.

Pogalad, Meikel, Silvana Sondak, Edwin Nani, Yenni Utiarahman, Triyanti Hunowu Moh Syarief Hida. 2009. Analisis Pengembangan Obyek Wisata (The Tourism Of Development) Terhadap Tingkat Kunjungan Wisatawan di Pentadio Resort Kabupaten Gorontal. Dinas Pariwisata Kebudayaan Komunikasi dan Informatika Kabupaten Gorontalo.

Putra, I Nyoman Darma dan I Gede Pitana. 2010. Pariwisata Pro-Rakyat Meretas Jalan Mengentaskan Kemiskinan di Indonesia. Jakarta: Kementerian Kebudayaan dan Pariwisata.

Rangkuti, Freddy. 2005. Analisis SWOT Teknik Membedah Kasus Bisnis. Jakarta: PT. Gramedia Pustaka.

Rencana Pembangunan Jangka Menengah Desa (RPJM Desa Selong Belanak ) 2011 Kecamatan Batudaa Pantai Kabupaten Gorontalo.

Undang-undang Republik Indonesia Nomor 10 Tahun 2009 Tentang Kepariwisataan. http://yotama-gorontalo.blogspot.com. Laporan Pokok Pikiran Yotama (Yosep 
Tahir Ma'ruf). Diakses pada tanggal 14 April 201 